\title{
WHY WOULD THE DEUTERONOMISTS TELL ABOUT THE SACRIFICE OF JEPHTHAH'S DAUGHTER?**
}

\author{
Thomas C. Römer \\ University of Lausanne, BFSH-2, 1015 Lausanne, \\ Switzerland
}

\section{Introduction}

Nowadays the Deuteronomistic historians could certainly not be described as 'politically correct', and this for numerous reasons. In the so-called Deuteronomistic History (Dtr) which I still believe to have been written during the Exile, ${ }^{1}$ we find indeed segregationism (esp. in Deuteronomy ${ }^{2}$ ) and imperialism (esp. in Josh. 1-12), both these ideologies presented from an upper class perspective. ${ }^{3}$ But should we also blame the Deuteronomists (Dtrs) for having transmitted the story in Judg. 11.29-40 where a seemingly impetuous and cruel Jephthah is going to kill his only and unnamed daughter to accomplish a vow made to YHWH who appears to be as cruel as Jephthah? No wonder, this story has become one of the 'classics' in feminist studies of the Hebrew Bible. Most recent analyses of Judg. 11.29-40 have been done by women, including Phyllis Trible, Mieke Bal, J. Cheryl Exum, Lillian Klein and many others. ${ }^{4}$ These studies are focused in quite

* Paper presented at the SBL annual meeting 1995, Philadelphia.

1. This does not mean that deuteronomism started with the Exile. I agree with N. Lohfink, 'Kerygmata des Deuteronomistischen Geschichtswerks', in J. Jeremias and L. Perlitt (eds.), Die Botschaft und die Boten (Festschrift H.W. Wolff; Neukirchen-Vluyn: Neukirchener Verlag, 1981), pp. 87-100, that some texts of the DH (e.g. Josh. 1-12*) were probably written during the reign of Josiah.

2. Particularly Deut. 7.1-6; 12.2-5.

3. In 1-2 Samuel and 1-2 Kings the people almost disappears from the scene.

4. P. Trible, 'The Daughter of Jephthah: An Inhuman Sacrifice', Texts of 
different ways on the fact that the story has been written and traditionally read from the perspective of Jephthah. We should therefore pay more attention to the daughter who offers herself for sacrifice and who is 'celebrated' in one way or another at the end of the story. I do not intend to do further work in the feminist approach, for I am unable to do so. I would rather like to pick up another question which is hardly asked: how does such a story fit in the context of the DtrH and the Dtr ideology? Or to take up the title of this paper: why would the Deuteronomists tell about the sacrifice of Jephthah's daughter? In order to answer this question I shall start with a few diachronic considerations.

\section{Diachronic Analysis}

It is quite obvious that the story of Jephthah's vow and sacrifice belongs to another literary level than the surrounding verses. First, it is quite astonishing, that after Judg. 11.29 where the spirit of YHWH comes upon Jephthah, the same feels the urge to make a vow to God. ${ }^{5}$ In parallel texts as Judg. 3.10; 14.19 and 1 Sam. 11.6 the intervention of the רוח יהוה immediately causes the defeat of the enemy. The Wiederaufnahme of the final words of v. 29 in v. 32a signals the vow sequence in vv. 30-31 as a redactional interruption between vv. 29 and

Terror: Literary-Feminist Readings of Biblical Narratives (Philadelphia: Fortress Press, 1984), pp. 93-115; M. Bal, Death and Dissymetry: The Politics of Coherence in the Book of Judges (Chicago: The University of Chicago Press, 1988), pp. 41-68; J. Cheryl Exum, 'On Judges 11', in A. Brenner (ed.), A Feminist Companion to Judges (The Feminist Companion to the Bible, 4; Sheffield: Sheffield Academic Press, 1993), pp. 131-45; L.R. Klein, The Triumph of Irony in the Book of Judges (JSOTSup, 68; Bible and Literature Series, 14; Sheffield: Almond Press, 1989), pp. 83-99; idem, 'A Spectrum of Female Characters', Brenner (ed.), A Feminist Companion to Judges, pp. 24-33; E. Fuchs, 'Marginalization, Ambiguity, Silencing: The Story of Jephthah's Daughter', in Brenner (ed.), A Feminist Companion to Judges, pp. 116-30; P.L. Day, 'From the Child is Born the Woman: The Story of Jephthah's Daughter', in P.L. Day (ed.), Gender and Difference in Ancient Israel (Minneapolis: Fortress Press, 1989), pp. 58-74; B. Gerstein, 'A Ritual Processes: A Look at Judges 11.40', in M. Bal (ed.), Anti-Covenant: Counter Readings Women's Lives in the Hebrew Bible (Bible and Literature Series, 22; Sheffield: Almond Press, 1989), pp. 175-93.

5. W. Richter, 'Die Überlieferungen um Jephtah. Ri 10,17-12,6', Bib 47 (1966), pp. 485-556 (491). 
33. ${ }^{6}$ We may also note that 12.1-6 alludes to Jephthah's 'crossings', but seems to ignore the events related to the vow and sacrifice story ${ }^{7}$ the root עבר is a leitmotif of a sort throughout the whole Jephthahcycle,${ }^{8}$ but does not occur in the vow report. The fact that Jephthah's house is supposed to be in Mizpah is only told in 11.34, and not in the other verses mentioning Mizpah or Mizpeh-Gilead in Judges 10-12. According to 12.1 Jephthah rather seems to live in a place called Zaphon. ${ }^{9}$ One may also consider the fact that the narrative about Jephthah's daughter is the only one to belong to the private sphere. In accordance with this the Ammonites, the enemies of the people of Israel, have become in 11.36 Jephthah's 'private' adversaries. ${ }^{10}$

We therefore conclude that the vow-story $(11.30-31$ [32], 34-40) did not originally belong to the war account in $11.29,33 ; 12.1-6$, which it interrupts. There is an inclusio between v. 30: 'Jephthah vowed a vow' and v. 39a: "he did according to the vow he vowed'," which means that vv. $39 \mathrm{~b}$ and 40 are to be considered as a note standing outside the narrative unit. But this is not necessarily significant for diachrony.

In spite of a widely held opinion, ${ }^{12}$ the account of Jephthah and his daughter is not an old independent story that was later inserted in ch. 11. I argue that the story never existed independently, but was composed by a redactor to fit in its present context. Verse 30 is indeed not the beginning of an independent story, and v. 32, as we have already seen, picks up v. 29. This means that the author-redactor intended to create a sort of 'tension' between the gift of the spirit and the vow. As holistic readings have often underlined, Jephthah's vow appears after

6. Cf. also B.G. Webb, The Book of Judges: An Integrated Reading (JSOTSup, 46; Sheffield: JSOT Press, 1987), p. 62.

7. H.W. Richter, Traditionsgeschichtliche Untersuchungen zum Richterbuch (BBB, 18; Bonn: Peter Hanstein, 1963), p. 326: According to 11.39 Jephthah has been at home for two months, whereas in 12.1-6 his has not come home yet.

8. $10.8,9 ; 11.17,18,19,20,29 t e r, 32 ; 12.1$ bis, 3, 5bis, 6; cf. R. Polzin, Moses and the Deuteronomist. I. A Literary Study of the Deuteronomistic History (New York: Seabury Press, 1980), pp. 179-81.

9. Richter, 'Überlieferungen', p. 490.

10. Fuchs, 'Marginalization', p. 123.

11. R.G. Boling, Judges: Introduction, Translation and Commentary (AB, 6A; Garden City, NY: Doubleday, 1975), p. 209.

12. Richter, 'Überlieferungen', p. 516; M. Görg, Richter (NEB, 31; Würzburg: Echter Verlag, 1993), p. 67. 
v. 29 as due to lack of faith. ${ }^{13}$ The tragic outcome of a vow that was not necessarily hasty and unconsiderate, ${ }^{14}$ increases the ambiguity of Jephthah's character. So, the question we have to ask is: would the Dtrs have been interested in telling such a story?

\section{May We Call the Vow-story 'Deuteronomic'?}

In Samuel's farewell speech (1 Sam. 12), clearly a Dtr production, Jephthah appears in v. 11: 'Then YHWH sent Jerubbaal, Bedan, ${ }^{15}$ Jephthah and Samuel, and he delivered you from the hands of your enemies on every side'. Jephthah belongs to the happy few that are chosen to represent YHWH's intervention during the time of the Judges. Would this have been possible after the story of his daughter's sacrifice ? This brings us to our second point: the Dtr attitude towards human sacrifice. In his commentary on Judges, James Martin writes: 'Jephthah must have envisaged human sacrifice... The Deuteronomist passes no judgement on the practice; he simply records it. ${ }^{16}$ Such a statement is hardly understandable, since a promise of human sacrifice would be no other than a transgression of Deuteronomic Law ${ }^{17}$ (cf. Deut. $12.29-31 ; 18.10$ ). There is, however, one text which was admitted in the DtrH and which relates to a human sacrifice. ${ }^{18}$ According to $2 \mathrm{Kgs} \mathrm{3.27,} \mathrm{King} \mathrm{Mesha} \mathrm{of} \mathrm{Moab} \mathrm{who} \mathrm{is} \mathrm{afraid} \mathrm{to} \mathrm{lose} \mathrm{the} \mathrm{battle}$ against Israel, offers his firstborn son as a holocaust. This action provokes great 'anger' (קצף) and the Israelites return to their land. It is

13. Cf., for instance, P. Trible, 'Daughter', p. 96; R. Bartelmus, 'JephthaAnmerkungen eines Exegeten zu G.F. Händels musikalisch-theologischer Deutung einer «entlegenen» alttestamentlichen Tradition', TZ 51 (1995), pp. 106-27 (115).

14. T.W. Cartledge, Vows in the Hebrew Bible and the Ancient Near East (JSOTSup, 147; Sheffield: JSOT Press, 1992), p. 179. Cf. already G.F. Moore, $A$ Critical and Exegetical Commentary on Judges (ICC; Edinburgh: T. \& T. Clark, 2nd edn, 1908), p. 299.

15. We cannot discuss here the enigma of 'Bedan', cf. A. Caquot, P. de Robert, Les Livres de Samuel (CAT, 6; Geneva: Labor et Fides, 1994), p. 149.

16. J.D. Martin, The Book of Judges (CNEB; Cambridge: Cambridge University Press, 1975), p. 145.

17. Cf. R.G. Boling, 'Jephthah', $A B D$, II, pp. 680-83 (681).

18. Generally, $2 \mathrm{Kgs} \mathrm{3.6-27}$ is considered pre-Dtr. According to E.A. Knauf, Die Umwelt des Alten Testaments (NSKAT, 29; Stuttgart: Katholisches Bibelwerk, 1994), p. 130, the story is a Judaean interpretation of the Israelite annals in $2 \mathrm{Kgs}$ 3.4-5. 
not astonishing that the exact meaning of the Hebrew text should remain obscure. The pre-Dtr version probably referred to the victorious anger of Kemosh against Israel; in the interpretatio deuteronomistica there is no more allusion to Kemosh. As Würthwein puts it, the Dtr version alludes to a numenous anger (which is identical with YHWH's one) and which pushes the Israelites to leave a country where things as horrible as human sacrifices are performed. ${ }^{19}$

According to the Dtrs, the worst thing Israel's and Judah's rulers did was to 'make children pass through the fire' ( 2 Kgs $16.3 ; 17.17$; 21.6) and it was Josiah, the Dtr's favorite, who brought this abomination to an end ( $2 \mathrm{Kgs} \mathrm{23.10).}{ }^{20}$ It is therefore hard to believe that in the Dtr edition of Deuteronomy to 2 Kings a divinely inspired saviour should have something to do with human sacrifice. We may also allude to 1 Samuel 14 , which certainly belonged to the DtrH. In this story Jonathan risks his life, because he unknowingly acted against the oath of his father. But he is rescued by the people and not put to death.

Thus, the above considerations indicate that the account of Jephthah's sacrifice has to be understood as a post-Dtr text. ${ }^{21}$ This statement may be confirmed on the literary level. The formulation of Jephthah's vow is a sort of patchwork of other Old Testament texts. ${ }^{22}$ The introduction and the protasis have a close parallel in Num. 21.223

19. E. Würthwein, Die Bücher der Könige: 1.Kön. 17-2.Kön 25 (ATD, 11.2; Göttingen: Vandenhoeck \& Ruprecht, 1984), p. 284. Cf. also J. Robinson, The Second Book of Kings (CNEB; Cambridge: Cambridge University Press, 1976), pp. 37-38.

20. G.N. Knoppers, Two Nations Under God: The Deuteronomistic History of Solomon and the Dual Monarchy (HSM, 53; Atlanta: Scholars Press, 1994), II, p. 186 n. 24.

21. Cf. also U. Becker, Richterzeit und Königstum: Redaktionsgeschichtliche Studien zum Richterbuch (BZAW, 192; Berlin: W. de Gruyter, 1990), p. 221. Becker, however, thinks that the story may be old, but its insertion certainly due to a post-Dtr redactor.

22. D. Marcus, Jephthah and his Vow (Lubbock, TX: Texas Technical Press, 1986), pp. 20-21, offers a convenient synopsis.

23. The classification of Num. $21.1-3$ is quite difficult. It was traditionally ascribed to ' $J$ '. Today, most scholars agree that the insertion of this notice is due to one of the latest redactors, cf. J. Scharbert, Numeri (NEB, 27; Würzburg: Echter Verlag, 1992), p. 83. 
and the first part of the apodosis is almost identical with Josh. $2.19 \mathrm{a}^{24}$ which, as Van Seters ${ }^{25}$ has shown, belongs to a post-Dtr stratum.

As to the final notice in vv. 39b-40 that mentions a alluding to a girls' commemoration of Jephthah's daughter, the nearest parallel is to be found in 2 Chron. 35.25, which is about the commemoration of the dead Josiah, a practice that is also called על עלישראל.

It has often been observed that the sacrifice of Jephthah's daughter is closely linked to the Aqedah story in Genesis 22. In both cases the offering is a עולה (Gen. 22.2; Judg. 11.30) and the victim is presented as his or her father's 'only' (דיד', Gen. 22.2; ידידי, Judg. 11.34) child. Parallel to Abraham calling 'my son' (Gen. 22.7) we have Jephthah's exclamation 'my daughter' (Judg. 11.35). There is also quite an ironical correspondence between Abraham's confidence that God will 'see' the victim for the sacrifice (Gen. 22.8) and Jephthah seeing his daughter who is thereby designated as to be offered to God (Judg. 11.35). Both stories have an outcome related to the issue of the offspring of the father. After an animal is substituted for Isaac, God promises to Abraham that he will have countless descendants (Gen. 22.17), whereas Jephthah's daughter disappears without having known a man (Judg. 11.39). The 'happy' end of Genesis 22 is transformed into a tragic one. So it seems quite clear that the author of Judg. 11.30-40 knows Genesis 22 and that he uses the 'Binding of Isaac' as the background for his own construction. Recent studies on Genesis 22, especially Timo Veijola's, ${ }^{26}$ have shown that this text has to be dated into the postexilic time. If the author of Judg. 11.30-40 knew of the Aqedah he can hardly be earlier. He is then certainly later than the Dtr edition of the book of Judges. In A Feminist Companion to Judges

24.

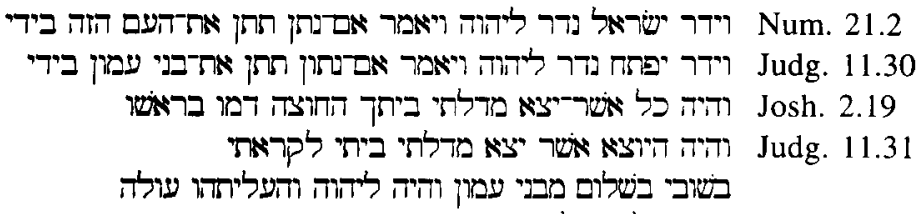

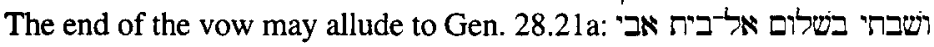

25. J. Van Seters, In Search of History (New Haven: Yale University Press, 1983), p. 325.

26. T. Veijola, 'Das Opfer des Abraham-Paradigma des Glaubens aus dem postexilischen Zeitalter', ZThK 85 (1988), pp. 129-64. Cf. also F. García López, 'Gen 22, entre la interpretación Histórico-Crítica y la Literario Teológica', F. García López and A.G. García (eds.), Biblia, Literatura e Iglesia (Salamanca: Publicaciones Universidad Ponitificia, 1995), pp. 47-62. 
Adrien Janis Bledstein has underlined the difference between the tale of Jephthah's daughter and other stories in Judges. The former account, she tells us, reminds her of ' $\mathrm{J} \cdot{ }^{27}$ If this does mean a 'Yahwist' à la Van Seters, who presupposes DtrH, she might be on the right track. Anyhow, if Judg. 11.30-32, 34-40 appears as an insertion into $\mathrm{DtrH}$, we have to ask our next question:

\section{Why Was the Story Told?}

The tale of Jephthah's vow and sacrifice contains numerous motifs which can be found in folk literature all over the world: ${ }^{28}$ the motif of vowing to sacrifice to a deity or a demon the first thing or person to be met; the motif of a silly vow that brings disaster on its author; the motif of the father who is obliged to offer his own child. We may quote here A. Graeme Auld commenting on Judg. 11.30-40: 'I suppose one could argue that the telling can be so brief because this sort of story was well known' ${ }^{29}$ If we put together all the motifs we mentioned the best parallels to the Jephthah story come from the Hellenistic world, as already noted by Walter Baumgartner. ${ }^{30}$ Scholars refer quite often to Servius, the commentator on the Aeneid of Virgil. ${ }^{31}$ According to Servius, Idomeneus, caught in a storm on the sea, promised to Poseidon that if he reached land safely, he would offer him the first thing to be met, which turned out to be his son. But this is a quite late tradition ${ }^{32}$ and the victim is a son, not a daughter. So we had better turn to another tradition which plays a very central role in Greek mythology: the legend of Iphigenia. The Traditionsgeschichte regarding Iphigenia is at least as confusing and complicated as the history of traditions in Old Testament studies. Iphigenia is first mentioned in the Kypria of Stasinos, an epic of maybe the seventh or sixth

27. A.J. Bledstein, 'Is Judges a Woman's Satire on Men Who Play God ?', in Brenner (ed.), A Feminist Companion to Judges, pp. 34-54 (53).

28. Cf., e.g., Marcus, Jephthah, pp. 40-41.

29. A.G. Auld, Joshua, Judges and Ruth (The Daily Study Bible; Edinburgh: Saint Andrew Press; Philadelphia: Westminster Press, 1984) p. 200.

30. W. Baumgartner, 'Jephtas Gelübde', AfR 18 (1915), pp. 240-49; idem, 'Israelitisch-griechische Sagenbeziehungen', in Zum Alten Testament und seiner Umwelt. Gesammelte Aufsätze (Leiden: E.J. Brill, 1959), pp. 147-78 (152-54).

31. Baumgartner, 'Gelübde', p. 243; Marcus, Jephthah, p. 41.

32. The Aeneid was written in the first century BCE; Servius lived about $400 \mathrm{CE}$. 
centuries BCE of which we only possess a few summaries. ${ }^{33}$ In the context of this paper we cannot deal with the complexity of the Iphigenia material, as for instance her possible identification with Artemis or the various cults and rituals related to the goddess. If we focus on the literary level we discover an enormous diversity. One may find different reasons for the necessity of the sacrifice: a vow made by Agammemnon, an oracle, the wrath of Artemis. The fate of Iphigenia is also multifarious. In some versions she is actually killed by her father, in other versions an animal is substituted for her, and she is taken away by the goddess to serve her as a virgin and priestess. Curiously the substitution pattern seems to be older than the death pattern. ${ }^{34}$ Both patterns can be found in Euripides' tragedies. In Iphigenia in Tauris (412 BCE), Artemis substitutes a hind and carries Iphigenia off to Asia to be her priestess. As to Iphigenia in Aulis (405 BCE) most scholars agree that the original play ended with the death of the maiden..$^{35}$

I would like to argue that the author of the tale of Jephthah's daughter did know the Iphigenia tradition, especially as it appears in Euripides. Before setting forth the evidence supporting this thesis, we may recall that the dramatic or lyric arts often interpreted the Jephthah story according to Euripides' Iphigenia. This is the case with the sixteenth-century humanist George Buchanan and with Reverend Thomas Morell who wrote the libretto for Händel's 'Jephthah'. ${ }^{36}$ But let us go back to Judg. 11.30-40. Since David Kimchi, it has been

33. The other contemporary attestation is the Hesiodic Catalogue, cf. K. Dowden, Death and the Maiden: Girl's Initiation Rites in Greek Mythology (London: Routledge, 1989), pp. 9-11. Against his statement that Homer may have known the legend of Iphigenia, see P. Bonnechere, Le sacrifice humain en Grèce ancienne (KERNOSSup, 3; Athens: Centre International d'Etude de la Religion Grecque Antique, 1994), pp. 39-41, see also n. 99: 'Pourquoi faudrait-il absolument qu'Homère ait connu tous les développements postérieurs à son œuvre?'; J.-M. Glikson, Iphigénie de la Grèce antique à l'Europe des Lumières (Paris: Presses Universitaires, 1985), pp. 13-15.

34. Bonnechere, Le sacrifice humain, pp. 41-42.

35, Cf., e.g., G.M.A. Grube, The Drama of Euripides (repr.; London: Methuen; New York: Barnes \& Noble, 1941), pp. 437-38; W. Stockert, Euripides, Iphigenie in Aulis (Wiener Studien Beiheft, 16.1; Vienna: Verlag der österreichischen Akademie der Wissenschaften, 1992), pp. 79-81.

36. Cf. Bartelmus, 'Jephta', pp. 117-18. In those plays Jephthah's daughter is named 'Iphis'. As in Euripides we find a mother and a virtual fiancé. 
claimed from time to time that Jephthah did not kill his daughter but consecrated her as a virgin to the service of YHWH's sanctuary. ${ }^{37}$ Even if the arguments for a literal interpretation of the text are much stronger, it is not totally impossible to adopt a non-sacrificial reading. The ambiguity in Judg. 11.30-40 might then have been intended. The author would have known both endings of the Iphigenia myth and tried to bring them together. For the plot of Judges 11 as for Euripides, there is no real contradiction between the two endings. Killed or dedicated to a divinity the girl will disappear as a 'virgin' and will not enter the genealogy of her family. ${ }^{38}$ There are other parallels between Jephthah and Agamemnon and between Jephthah's daughter and Iphigenia.

According to Iphigenia in Tauris (18-23), King Agamemnon had vowed to sacrifice to the goddess the loveliest offspring the year would give birth to and it turned out to be Iphigenia. As for Jephthah, his vow is connected with a military crisis. And both military leaders are depicted in a certain ambiguity. Both feel sorry for themselves ${ }^{39}$ and almost blame their daughters, who come running to greet them, ${ }^{40}$ for having to sacrifice them. In Euripides as in Judges 11, the 'real hero' is the maiden, since she accepts voluntarily to be sacrificed and she pushes her father to do so. ${ }^{41}$ There are also similarities in the topic of the girl being lamented or remembered by other girls, so that she might survive in the memory of future generations. ${ }^{42}$ Perhaps we may also establish a link between the commemorating or lamenting over Jephthah's daughter during four days and a girls' initiation festival at Brauron which took place every fourth year? This festival

37. Cf. Marcus, Jephthah.

38. See also Bonnechere, Le sacrifice humain, pp. 41-42.

39. Iphigenia at Aulis 536: 'Even to this goes my affliction, unfortunate as I be' (translation inspired by A.S. Way, Euripides in Four Volumes [London: Heinemann; New York: Putnam's Sons, 1916], I); Judg. 11.35.

40. Iphigenia at Aulis 631-32: 'O mother, let me run ahead of you! Do not be angry at me if I am first to clasp my father against my heart'; Judg. 11.34.

41. Iphigenia at Aulis 1375-76: 'I thought over it, Mother, and understood. I am to accept my own death. But I mean to have this done gloriously, without any weakness'; 1551-56: 'And said: my father, here I am. Dispose of me. I have come on my own resolve, for my country and the whole of Greece to offer my body to sacrifice' [the authenticity of the last passage is contested]; Judg. 11.36.

42. Iphigenia at Aulis 1398-99: 'So will my memory be kept for a long time'; 1490-96: 'Sing maidens. ... so be my name celebrated'; Judg. 11.37-40. 
which was in some ways bound to the myth of Iphigenia marked the end of the girls' status as 'virgins' in the sense that they became nubile women. ${ }^{43}$ It is difficult to say if the finale of Judges 11 alludes to such rites. There is no evidence for such a festival in monarchic or postexilic Judaism. So there might be no real aetiological purpose at the end of the story, ${ }^{44}$ just some borrowing from Greek tradition. Anyway, the above listed parallels between Jephthah's daughter and Iphigenia make quite clear what the author of Judg. 11.30-40 intended to do: he wanted to present Jephthah's daughter as the Hebrew Iphigenia. Why was he interested in doing so?

To answer this question we have to consider the influence of Greek culture on Judaism since the middle or the end of the Persian period. As Albert de Pury and others have shown, the Greek 'canon' to which Aeschylus and Euripides belonged fascinated part of the Jewish intelligentsia, especially those of Alexandria. ${ }^{45} \mathrm{We}$ cannot deal here with the general question of Greek influence on Old Testament literature which Van Seters, for instance, has claimed for his late exilic or postexilic 'Yahwist'. ${ }^{46}$ What we should consider is the fact that some trends of post-exilic Judaism disagree with the 'official' Dtr ideology of retribution and theodicy. This is particularly clear in the books of Job and Qohelet. Qohelet's answer to deuteronomism is scepticism. Humans have to manage their lives without any guarantee they will understand the divine plans. The same mentality occurs in the Greek tragedies. Recent scholarship has characterized Euripides' Iphigenia with three concepts: tragedy, ambiguity and irony. ${ }^{47}$ For Judg. 11.30 40 we have already analysed the first and second topic. But there are also some ironic or even subversive features.

First of all, the story contains allusions to the Exodus tradition

43. Dowden, Death, pp. 26-32; Bonnechere, Le sacrifice humain, pp. 26-35; בתולה may also be translated by 'adolescence' and understood as a social recognition of puberty, cf. K. Keukens, 'Ri 11,37f.: Rite de passage und Übersetzungsprobleme', $B N 19$ (1982), pp. 41-42.

44. Cf. also Boling, Judges, p. 210.

45. A. de Pury, 'Le canon de l'Ancien Testament', Protestantisme et construction européenne. Actes du Colloque des Facultés de théologie protestante des pays latins d'Europe (Brussels: Ad Veritatem, 1991), pp. 25-45 (37-41).

46. Cf., e.g., A Prologue to History: The Yahwist as Historian in Genesis (Louisville, KY: Westminster/John Knox Press, 1992).

47. Cf. Gliksohn, Iphigénie, pp. 22-24; Bonnechere, Le sacrifice humain, pp. 267-72. 
which is in the very centre of the Dtr theology. Four times the author uses the verb $\mathrm{N}^{\prime}$ ' and the coming out of the maiden to greet his victorious father with tambourines and choral dances corresponds exactly to Miriam's celebration of the overthrow of Egypt at the Red Sea in Exod. 15.20-21.48

If we may, with Steven McKenzie, detect a Dtr 'Mizpah-connection', ${ }^{49}$ the localization of a human sacrifice at Mizpah could be a hidden anti-Dtr polemic.

Finally, I would like to lay stress on a crux in 11.37 where according to the MT Jephthah's daughter says: 'I will go down on the mountains...'. Almost all commentators rectify and translate 'I will wander' or similarily. ${ }^{50} \mathrm{I}$ do not consider this alteration to be necessary. The expression 'coming down to the mountains' is a technical term for a theophany, especially in the Sinai tradition (Exod. 19.18, 20; cf. also 3.8). So its use in Judg. 11.37 may be ironical: there is no more God coming down on the mountains, the girl has to go on her own etsi Deus non daretur... The Dtr conception of direct divine intervention for salvation or punishment does not work any more. Susan Niditch stated that 'the neutrality of the narrator in Judg. 11.2940 is fascinating and shocking' ${ }^{51}$ To this we may add that there is also a 'neutrality' of God. Indeed, the text is silent about God's reaction to the deed and he does not intervene at all. Again, we are not so far from Euripides' tragedies, where, according to Gliksohn, the divinity absents itself from the human drama. ${ }^{52}$ Thus, the story of Jephthah's sacrifice puts forth an atmosphere of fatality. The vow has been pronounced and has to be accomplished. But it would have been preferable that this vow had never been made. We have then the same

48. Cf. also 1 Sam. 18.6-7.

49. S.L. McKenzie, 'Cette royauté qui fait problème', in A. de Pury, T. Römer, J.-D. Macchi (eds.), Israël construit son histoire: L'historiographie deutéronomiste à la lumière des recherches récentes (Le Monde de la Bible, 34; Geneva: Labor et Fides, 1996), pp. 267-95.

50. Scholars often postulate a root רור, cf. Boling, 'Judges', p. 209; J. Gray, Joshua, Judges, Ruth (NCBC; Grand Rapids: Eerdmans; Basingstoke: Morgan \& Scott, 1986), p. 319; J.A. Soggin, Le livre des Juges (CAT, 5b; Geneva: Labor et Fides, 1987), p. 186.

51. S. Niditch, War in the Hebrew Bible: A Study in the Ethics of Violence (Oxford: Oxford University Press, 1993), p. 33.

52. The deus ex machina substituting an animal for the girl is used by Euripides in a quite subversive manner, cf. Gliksohn, Iphigénie, p. 45. 
ideology as in Qoh. 5.3-4: 'When you make a vow to God, do not delay in fulfilling it, for there is no favour for fools; fulfil your vow. It is better not to vow than to make a vow and not to fulfil it.' In a way, Judg. $11.30-40$ is a narrative application of Qohelet's sceptical maxim. This means that the author of the story of Jephthah's sacrificing his daughter is a colleague of Qohelet, trained as he was in Jewish and Hellenic culture ${ }^{53}$ and criticizing the official Dtr theology. ${ }^{54}$ By inserting his story in the Dtr context of the Jephthah cycle, he makes Jephthah less heroic and confronts him with a courageous daughter thus creating an open and ambiguous text. ${ }^{55}$ By making the Hebrew Iphigenia accept her sacrifice the narrator sacrifices the Dtr ideology of divine pedagogics and confronts the reader of the DtrH with theological problems which have still not been solved and might never be solved.

\section{ABSTRACT}

It is commonly assumed that the story of Jephthah's vow refers to an 'old tradition' that was integrated into the Deuteronomistic History. But such a view is contrary to Dtr ideology which is absolutely hostile to any human sacrifice (2 Kgs 16.3; 17.17, $31 ; 21.6$ etc.). A literary-critical approach to Judges 11 shows that vv. 30-31[32] and 34-40 may be considered as post-Dtr.

The author of Judg. 11.30-40 seems to know the story of the Aqedah, but he is not willing to make a happy ending. There is a tragic dimension in the story and quite an Hellenistic atmosphere (the best parallels to Judg. 11.30-40 may be found in Hellenistic texts). So this text should be considered an insertion from the end of the Persian or beginning of the Hellenistic periods. The author tends to show that Jewish classics can be as tragic as Greek ones.

53. Let us just remember that the author of Judg. 11.30-40 is refering also to Gen. 22; he also picks up some motives from $2 \mathrm{Kgs} 3$.

54. It is commonly supposed that Qoh. 5.3-4 quotes from Deut. 23.22-24. If this is the case, the 'quotation' in Qoheleth seems quite ironical, since Deut. 23.22-24 insists above all on the fulfilment of the vow. Qoheleth turns Deut. 23.23 into its contrary.

55. This openness and ambiguity explains the difficulties of Jewish and Christian interpretaters handling this text, cf. U. Hübner, 'Hermeneutische Möglichkeiten. Zur frühen Rezeptionsgeschichte der Jefta-Tradition', in E. Blum et al. (eds.), Die Hebräische Bibel und ihre zweifache Nachgeschichte (Festschrift Rolf Rendtorff; Neukirchen-Vluyn: Neukirchener Verlag, 1990), pp. 489-501. 